\author{
DIÁSPORA: \\ Partilhas de um Process Drama entre UFU e UFGD
}

\author{
DIÁSPORA \\ Comparte um Proceso de Drama entre UFU y UFGD
}

\author{
DIASPORA \\ Sharing of a Process Drama between UFU and UFGD
}

\author{
Flávia Janiaski ${ }^{1}$ \\ Wellington Menegaz ${ }^{2}$
}

\begin{abstract}
RESUMO
Este artigo, construído a quatro mãos, nasceu do anseio de produzir reflexões acerca das experiências cênico-pedagógicas desenvolvidas pelos autores no contexto do Curso Partilhas Teatrais em Extensão - ateliês e redes de aprendizagens teatrais na escola básica, mais especificamente no módulo de agosto de 2017 - Abordagens práticas e teóricas: do Drama na educação básica - em que foi desenvolvido o processo de Drama Diáspora. Nessa escrita apresentaremos aspectos relacionados à criação, estrutura e desenvolvimento do processo Diáspora.
\end{abstract}

PALAVRAS-CHAVE: process drama, trocas teatrais, formação docente, artistapesquisador

\title{
RESUMEN
}

Este artículo, construído a cuatro manos, nació del anhelo de producir reflexiones acerca de las experiências escénico-pedagógicas desrrolladas por los autores en el contexto del Curso Partilhas Teatrais em Extensão - ateliês e redes de aprendizagens teatrais na escola básica, más especificamente en el módulo de agosto de 2017 -. Enfoques prácticos y teórico del Drama en la educación básica - em que se desarrolló el proceso de Drama Diáspora. En esta escritura presentaremos aspectos relacionados con la creación, estrutura y desarrollo de proceso Diáspora.

PALABRAS CLAVE: proceso drama, intercambios teatrales, formación docente, artista-investigador.

\footnotetext{
${ }^{1}$ Professora do Curso de Licenciatura e Bacharelado em Artes Cênicas da Universidade Federal da Grande Dourados/UFGD e doutoranda do Programa de Pós-Graduação em Artes Cênicas da Universidade Federal da Bahia/UFBA com projeto de pesquisa a ser concluído no primeiro semestre de 2019. flajaniaski@hotmail.com. Área de pesquisa: Pedagogia do Teatro. Orientadora Prof. Dra. Célida Salume Mendonça. Bolsista de doutorado CAPES (Bolsa nacional e doutorado sanduíche - Universidade de Massachusetts/USA).

2 Professor do Curso de Teatro da Universidade Federal de Uberlândia. Mestre e doutor em Teatro pela Universidade do Estado de Santa Catarina.wellmenegaz@yahoo.com.br.
} 


\begin{abstract}
This article, written with four hands, come from the desire to reflect on the scenicpedagogical experiences developed by the authors within the project Partilhas Teatrais em Extensão - ateliês e redes de aprendizagens teatrais na escola básica. Especially the workshop in August/2017 - Practical and theoretical approaches: Drama in basic education. On the Workshop, we developed a Process Drama we call The Diaspora. In this article, we will present aspects related to the creation, structure and development of The Diaspora process.
\end{abstract}

KEYWORDS: process drama, theatrical exchanges, teacher training, artistresearcher.

\title{
O encontro de dois Artistas/Docentes/Pesquisadores
}

\author{
"Acalmou a tormenta. \\ Pereceram os que a estes mares ontem se arriscaram \\ E vivem os que por um amor tremeram \\ E dos céus os destinos esperaram" (Tribalistas, 2017).
}

Qual o sentido atual de partilha e diáspora? Será que o que partilhamos com os outros nos dias de hoje não são exatamente nossas pequenas diásporas? No tempo em que vivemos acompanhamos diariamente nas mídias sociais notícias (verdadeiras e falsas) de perseguições, intolerância e preconceito de tantas "minorias", que em sua maioria não partilham o mesmo país de nascimento, mas partilham gostos e escolhas de vida próprios, ou a mesma crença, ideais políticos etc. E sofrem, por suas escolhas, preconceitos e perseguições. Porque temos tanto medo do outro? Do diferente de mim? Do que ainda não conhecemos? Quem é aquele que está do outro lado do muro?

Foi com este sentimento de partilhar e de entender as pequenas diásporas que presenciamos no nosso dia a dia, que nasceu a vontade de troca entre nós dois, autores deste artigo. E o espaço próprio para este compartilhar surgiu da forma mais rica possível, através do Curso Partilhas Teatrais em Extensão - ateliês e redes de aprendizagens teatrais na escola básica.

Coordenar um dos módulos do curso, no caso, Abordagens práticas e teóricas: do Drama na educação básica, foi uma experiência rica em termo de trocas e aprendizados. O projeto Partilhas existe desde 2012, na edição de 2017 inovou com a 
ideia dos módulos. O objetivo era que um (a) professor (a) da educação básica ou ensino superior, residente em Uberlândia (MG), convidasse outro (a) professor (a) que tivesse afinidade com sua pesquisa. A partir desse chamado, pudemos, Flávia Janiaski e Wellington Menegaz (Tom), fazer nosso encontro para compartilhar experiências enquanto professores de Teatro.

Muitas afinidades marcam nossas trajetórias. Fomos coordenadores do subprojeto Teatro do Programa de Bolsas de Iniciação à Docência PIBID, como também somos professores de uma Licenciatura em Teatro, atuando entre outros componentes curriculares, nos estágios supervisionados. Sendo que Flávia como docente do Curso de Artes Cênicas da Universidade Federal da Grande Dourados UFGD e Wellington do Curso de Teatro da Universidade Federal de Uberlândia UFU.

O que nos motivou a propor esse módulo foi o fato de que ambos trabalhamos em nossas práticas pedagógicas com o Drama3 . Que pode ser definido como sendo “[...] uma investigação teatral de um pré-texto, por meio da criação de contexto ficcional, definição de papéis (roles) para os estudantes e professor bem como atividades teatrais a serem exploradas e investigadas" (PAULA, 2016, p. 18).

Nossas primeiras experiências com o Drama foram através do contato com processos desenvolvidos pela pesquisadora Beatriz Ângela Vieira Cabral (Biange) responsável por trazer o Process Drama para o Brasil -, porém em épocas e contextos distintos. Flávia conheceu esse método de ensino ainda durante sua graduação em Artes Cênicas na Universidade Estadual de Santa Catarina UDESC nas disciplinas de metodologia do teatro, participando de dois processos com sua turma de graduação, depois desenvolvendo ela mesma, sob orientação de Biange, um processo com adolescentes em seu estágio curricular supervisionado. Mais tarde, no mestrado voltou a ter contato com a professora e a metodologia e depois quando iniciou sua carreira docente (primeiro na educação básica, depois no ensino superior) trabalhou inúmeras vezes com o Drama.

Já Wellington teve seu primeiro contato com o Drama através de duas oficinas ministradas por Biange em Uberlândia (MG) (sendo a última delas no ano de 2010),

\footnotetext{
${ }_{3}^{3}$ Método de ensino também conhecido como process drama ou drama in education.
} 
após esse contato, buscou conhecer um pouco mais sobre o Drama através de artigos escritos por Biange. Aprofundou no doutorado seus estudos sobre o Drama, em sua tese investigou a associação desse método de ensino com a internet. Atualmente desenvolve processos de Drama na graduação, dentro do componente curricular Pedagogia do Teatro II e em algumas escolas de educação básica (através dos estágios supervisionados e do subprojeto Teatro PIBID).

Nessas experiências anteriores, tivemos acesso ao processo criado por Biange e Heloise Baurich Vidor, a partir do texto de David Campton Nós e Eles:

[...] Este texto conta a história, através do personagem do Escriba, de dois grupos de pessoas, A e $B$, que chegam a um lugar, que pode ser qualquer lugar, e passam a conviver nesse mesmo espaço. A convivência leva os grupos a quererem dividir o espaço e eles chegam à conclusão de que a melhor forma de dividi-lo é através da construção de um muro. Separados pelo muro, eles passam a imaginar o que os outros estão fazendo ou deixando de fazer e isso leva ambos os grupos a um estado de paranoia. (VIDOR, 2010, p.50)

Como premissa desse método de ensino, os participantes devem em determinado (s) momento (s) tomar decisões, no caso específico desse processo a principal decisão foi entre destruir ou manter o muro que os separam. Nas palavras de Vidor:

Nossa adaptação ao texto original conta com a interrupção da história no momento em que os grupos vão decidir pela derrubada ou manutenção do muro. No original eles optam pela derrubada, mas voltam a pensar que poderiam construir outro mais comprido, largo, forte, grosso. Neste momento do texto, nós sugerimos a realização de uma assembleia e uma votação entre as tribos, que agora estão duas de um lado e duas de outro, ponderando a presença do muro como algo que pode ou não ser eficaz. Assim, os participantes decidem se o muro deve ou não ser derrubado e discutimos quais as implicações de uma ou de outra opção. Isso mostra que o final é aberto e que, em cada contexto que a experiência é realizada, o muro pode ser derrubado ou não. (VIDOR, 2010, p.5)

Como tivemos nossos primeiros contatos com o Drama, quanto com este processo específico, em tempos distintos, estas experiências, assim como as reverberações das mesmas, ficaram guardadas em nossas memórias para serem partilhadas anos mais tardes, quando se deu o encontro entre nós. É interessante mencionar que percorrermos em alguns momentos de nossas trajetórias um caminho em comum, mas em tempos distintos, e que apesar estudarmos na mesma universidade, passarmos por processos de aprendizagem semelhantes, e já termos 
ouvido na época o nome um do outro e termos algumas referências e amigos em comuns, o encontro entre nós dois só aconteceu quando ambos já estavam concursados na UFGD, no caso de Flávia, e na UFU, no caso de Wellington.

Através de um amigo em comum, nosso encontro aconteceu em Dourados (MS) e as afinidades foram surgindo pouco a pouco, assim como o anseio de realizar algum trabalho juntos, partilharmos alguma experiência. A primeira partilha aconteceu quando Flávia realizou um processo de Drama junto ao PIBID de teatro da UFGD usando como pré-texto a peça Vestido de Noiva de Nelson Rodrigues. Foi um processo de Drama intenso e quando Wellington (que já vinha desenvolvendo processos usando como pré-texto a peça Boca de Ouro de Nelson Rodrigues) ficou sabendo se interessou e esta foi a primeira partilha entre nós. No entanto, em espaços físicos e temporais diferentes. Um em Uberlândia e outro em Dourados, mas com a mesma estrutura para os episódios. Evidentemente os resultados com cada grupo foram distintos. Estes processos nos levaram a maturar a ideia e o desejo de partilhar mais do que a estrutura para o Drama, partilhar de fato a construção e desenvolvimento de um processo de Drama.

O Curso Partilhas Teatrais em Extensão da UFU foi o espaço propício para realização deste desejo. Após o convite de Wellington, nos reunimos para preparar a estrutura do processo que seria feito primeiramente na UFU dentro do Partilhas e posteriormente no componente curricular Pedagogia do Teatro II (do Curso de Teatro UFU) e logo em seguida na UFGD com o PIBID/Teatro. O primeiro desafio foi a escolha da temática a ser trabalhada. Como estruturar um processo que gerasse estímulos e oportunidades de exploração teatral e de determinados conteúdos para grupos com realidades distintas?

Buscar o pré-texto adequado, que crie situações e problemáticas que possam interessar a todos os participantes, é sempre o primeiro desafio ao se pensar em um processo de Drama. A ideia do Drama de trabalhar com um pré-texto é uma oportunidade de ter liberdade para realizar as escolhas que melhor servirão ao grupo de trabalho. Para Cabral o pré-texto “[...] é o roteiro, história ou texto que fornecerá o ponto de partida para iniciar o processo dramático, e que irá funcionar como pano de fundo para orientar a seleção e identificação das atividades e situações exploradas" 
(CABRAL, 2006, p. 15). Neste sentido o pré-texto vai funcionar como um caminho que guiará o processo, um estímulo para a criação de uma narrativa coletiva que será construída em cada episódio por cada participante.

[...] os episódios não se constituem apenas em aglomerados de atividades ajuntadas acerca de uma situação, mas uma sequência em que se percebe uma relação estreita entre uma atividade e outra, em que aspectos de um episódio solicitam um desenvolvimento investigativo, que se efetivará no episódio posterior. Um processo de Drama propõe, assim, a investigação teatral de uma narrativa, investigação esta que vai se aprofundando de episódio em episódio. (DESGRANGES, 2010, p. 126-127).

Quais temas poderão contemplar todos os envolvidos? Dentre estes temas qual tem o potencial de tecer teatralidade? Qual proporcionará melhores oportunidades de jogo e trocas entre os participantes para a construção coletiva? Em meio a tantos questionamentos decidimos resgatar a experiência vivida através do processo Nós $e$ Eles. Ambos fomos marcados por esta experiência e vimos nela a possiblidade de trabalhar questões referentes a identidade, preconceitos, diferenças e medos, entre outras temáticas que surgiram no decorrer dos episódios. No entanto, apesar da riqueza e potencial desse processo, tínhamos a intenção de desenvolvermos juntos uma estrutura original para o Drama.

Após vários encontros, trocas de ideias e partilhas de conhecimentos, criamos uma estrutura para o Drama que batizarmos de Diáspora, inspirada no processo Nós e Eles. Importante ressaltar que além desse processo, outro estímulo poético foi essencial para a criação dessa estrutura, a música Diáspora de autoria dos Tribalistas, trio formado por Marisa Monte, Arnaldo Antunes e Carlinhos Brown. A escolha dessa música aconteceu, pois considerávamos que sua letra traz a atualização do conceito de diáspora, estabelecendo diálogo com os dias atuais. Como exemplo, citamos o seguinte fragmento: "Atravessamos o mar Egeu / O barco cheio de fariseus / Como os cubanos, sírios, ciganos / Como romanos sem Coliseu / Atravessamos pro outro lado / No Rio Vermelho do mar sagrado / Os Center shoppings superlotados / De retirantes refugiados" (Tribalistas, 2017).

$$
* * *
$$




\section{O processo}

Construir estratégias para conseguir o envolvimento dos participantes na proposta e o engajamento na construção da narrativa foi um dos principais objetivos para a preparação do processo de Drama Diáspora. Mas para que isso acontecesse era preciso, antes de tudo, que criássemos um contexto de ficção, que possibilitasse a imersão dos participantes nas atividades e investigação do tema, no caso, as várias possibilidades de diásporas que vivenciamos em nosso cotidiano. Para elucidar a importância do contexto de ficção no Drama, compartilhamos o pensamento de Cabral:

Ao fazer teatro/drama, entramos em uma situação imaginária - no contexto de ficção. A aprendizagem decorrente emerge desta situação e do fato de termos de responder a ela, realizar ações e assumir atitudes nem sempre presentes em nosso cotidiano. Como consequência, não ficamos restritos ao contexto "real" da sala de aula, nem a excursões ocasionais. (CABRAL, 2006, p.12. Grifo da autora).

A partir do tema diáspora, buscamos um contexto de ficção que abarcasse nossos objetivos. Após pensarmos em diversas possibilidades, chegamos em uma história ficcional, criada por nós, a partir de uma releitura e adaptação do processo Nós e Eles. Elaboramos então a seguinte história:

No início estaríamos em diversas regiões do Brasil, em cada local haveria uma dupla que possuía laços afetivos (amigos, parentes, namorados, casados etc.). Cada dupla saiu de sua cidade em busca de uma nova vida, em um novo lugar. Porém, por algum motivo a dupla foi separada durante sua trajetória. Com isso, seguiram caminhos distintos, rumo a suas diásporas cotidianas. Até se depararem cada um de um lado de uma fronteira física, um muro, que separava dois países em conflito. Os moradores de cada lado receberam uma proposta de emprego, por parte do governo de seu país - formar os "grupos de fronteiras", responsáveis pela proteção do muro. Porém, depois de dois anos, os países entram em um acordo de "paz", e cada "grupo de fronteira", teria a seguinte decisão: romper ou manter o muro?

Apoiados nessa história, nosso próximo passo foi planejar atividades teatrais com o intuito de explorar o contexto de ficção, e elaborar os papeis desenvolvidos pelos participantes e por nós coordenadores. Sobre esse último ponto, é importante 
ressaltar a importância do teacher in role, nos processos de Drama, que são os papeis desenvolvidos por quem coordena o processo.

[...] a elaboração do teacher in role representa as várias possibilidades de relação do professor com o grupo de drama e está totalmente conectado com o fluxo de informações que emergem durante o processo, e com a comunicação das informações entre professor-aluno e alunoprofessor. O teacher in role é, essencialmente, um facilitador da comunicação e uma oportunidade de mudança de paradigma. (VIDOR, 2010, p. 36).

Nesse processo assumimos os seguintes papeis: no segundo episódio Flávia e Wellington eram representantes do governo de cada um dos países, contratados para coordenar os "grupos de fronteira". O lado do muro que o papel de Flávia simbolizava, era de um país em que sua principal economia era a exploração de tecnologias multimídias e com forte poder financeiro, já o lado de Wellington tinha uma economia que vinha da valorização e preservação do meio ambiente, em especial da maior floresta do globo terrestre. Nesse encontro tínhamos um status alto, ou seja, estabelecíamos as regras que os moradores de cada lado do muro seguiriam. Já no terceiro episódio assumimos papeis de mediadores, um status médio, éramos contratados pelo governo de cada país, e nossa missão era estabelecer diálogo entre os moradores de cada lado do muro, para que os mesmos tomassem a decisão da manutenção ou não do muro.

\section{Primeiro encontro}

No primeiro encontro trabalhamos dois episódios. O objetivo do primeiro episódio era inserir o tema do processo, além de formar as duplas que seguiam sua caminhada em busca de um novo lugar para recomeçar, até o momento em que foram separadas. É importante destacar que a divisão foi feita a partir dos afetos e não de alguma diferença, ou seja, as duplas que caminhavam juntas tinham se escolhido por afinidades e lhes foram dados papeis com fortes vínculos afetivos, e em determinado momento de suas caminhadas elas foram bruscamente separadas. No segundo episódio, esses novos lugares foram formados, e as relações com pessoas que habitavam o mesmo começaram a se estabelecer. 


\section{Episódio 1 - A diáspora}

\section{Apreciar a música Diáspora:}

Os participantes escolheram um lugar na sala e deitaram de olhos fechados. Nesse momento escutaram a música Diáspora dos Tribalistas. Ocorreu uma pausa na música para leitura de um texto sobre diáspora. Nós, coordenadores, nos revezamos nessa leitura, falando às vezes alto e em outros momentos ao ouvido dos participantes. Logo em seguida a música voltou a tocar. O objetivo dessa atividade era propiciar as primeiras imersões dos participantes no processo, e consequentemente, na temática que vivenciariam.

\section{Caminhar pela sala:}

Levantaram e caminharam pela sala; passavam pelo outro e se olhavam; Instrução: "O que você vê no outro como igual a você, como o "nós". O que você vê no outro como diferente de você, como o "eles"?”.

\section{Abraçar/Laços para a viagem:}

Continuaram a caminhada, porém acrescentando os seguintes comandos: Uma batida - se abraçam em duplas (duração 1 minuto); Duas batidas - se olham (duração 1 minuto); Três batidas - Instrução "Se você fosse partir para um lugar distante o que diria para ela/ele?". Foi utilizado um pandeiro para fazer os comandos.

\section{Duplas para a diáspora:}

Durante a caminhada, pedimos que escolhessem uma pessoa com quem queriam fazer a diáspora. Instrução: "Se você fosse viajar para um lugar distante, se fosse fazer uma diáspora, quem você escolheria para ir junto?”. Após a escolha as duplas caminharam de mãos dadas pelo espaço.

\section{Distribuição dos papeis:}

Cada dupla recebeu uma ficha com dois papéis (um para cada); esses papéis eram as relações afetivas que iriam construir/explorar entre eles/elas. Pedimos que 
escolhessem quem faria qual papel. Os papeis distribuídos foram: Irmãos; Namorados; Avô/Avó e Neto/Neta; Pai/Mãe e Filho/Filha; Casal; Irmãos gêmeos; melhores amigos.

\section{Os laços:}

Após a divisão dos papéis cada dupla recebeu uma venda e lhes foi instruído que caminhassem pelo espaço com os olhos vendados. Esse foi um momento simbólico e sensorial. Começou a serem tecidas densidades da relação entre a dupla, especialmente um sentimento de confiança, gerado inicialmente pela falta física do sentido da visão - um precisava confiar no outro e contar com o outro para seguir em frente, para percorrer o caminho que precisavam seguir. Depois de um tempo, o uso do sentido do tato gerou uma proximidade ainda maior entre as duplas, que caminhavam de braços dados, "grudados" um no outro para criar a confiança necessária para se caminhar no escuro rumo ao desconhecido. A música Diáspora estava presente, novamente como estímulo auditivo para a imersão no jogo.

\section{A separação:}

Após um tempo de caminhada separamos as duplas e levamos cada um para um lado da sala; Instrução: "Sinta a solidão". Como mencionado acima, esta separação foi inesperada e abrupta, o que gerou nos participantes certa desorientação espacial (não sabiam por quem, nem para onde estavam sendo levados) e certa desorientação emocional, pois estavam sozinhos em um espaço desconhecido. Com os três grupos onde o processo foi realizado, houve uma forte reação por parte dos participantes. A "separação" gerou impacto emocional, e muitos participantes relataram após o fim do episódio que mesmo tendo claro que se tratava de um jogo de papéis, o lado emocional foi forte a ponto de fazê-los reviverem algumas separações e partidas pessoais. E todos se envolveram emocionalmente com a temática que iríamos trabalhar.

\section{O muro:}

Quando estavam posicionados nos seus locais colocamos o muro no centro da sala, separando os dois espaços. Ou seja, cada pessoa da dupla ficou de um lado do muro e foi dada aos participantes a seguinte instrução: 
Passou um ano desde que vocês foram separados. Faz um ano que vocês chegaram a um lugar desconhecido, com pessoas desconhecidas, e juntos tiveram que recomeçar. Para alguns isso pode ser quase que um exílio, até uma prisão. Para outros, uma oportunidade, uma segunda chance, um recomeço. A escolha é de vocês. A escolha é de vocês?

O texto foi dito com os participantes vendados. Logo em seguida pedimos para que tirassem as vendas. Veem o muro pela primeira vez. Tempo curto para sentirem e observarem esse novo lugar. Final do primeiro episódio.

\section{Intervalo de 15 minutos:}

O intervalo foi para deixarem um pouco a emoção criada ao longo do primeiro episódio e fazerem o distanciamento temporal necessário para o restante do processo. Por isso, optamos em começar o novo episódio fora dos papéis.

\section{Episódio 2 - um novo lugar}

\section{Um ano se passou:}

Os participantes ao voltarem para a sala vão cada um para o lado do muro que estavam antes do intervalo. Durante esse segundo episódio nós, coordenadores, nos separamos, cada um ficou de um lado do muro. Em roda inserimos a seguinte história:

Como vocês já sabem um ano se passou desde a separação. Desde que vocês tiveram que partir solitários, rumo a sua diáspora. E nessa viajem cada um foi para uma terra, tentar a sorte, uma nova vida. Cada um teve seus motivos para isso. Nessa nova terra havia um muro, uma fronteira dividindo as duas terras. Vocês foram habitar um lado desse muro, dessa fronteira. Essa nova terra era um novo mundo repleto de possibilidades. Hoje faz um ano que chegaram aqui. Ao longo desse um ano construíram sonhos, desejos e expectativas para uma nova vida.

\section{Imagens/Desejos:}

Fora dos papeis, cada participante pensou em um desejo do seu papel nesse novo lugar. Cada lado do muro foi dividido em dois grupos, e fizeram dois quadros de imagens contendo os desejos de um ou dois participantes. Depois de compartilharem as imagens, quem propôs o desejo se deslocava da imagem e falava sobre seu desejo. 
Essa atividade foi inspirada em uma das propostas presente no processo Nós e eles "Episódio 1. Quem somos? O que buscamos? A jornada” (VIDOR, 2010, p. 55-56).

Vale ressaltar, que na primeira vez que fizemos esse processo, não havia essas duas atividades iniciais do segundo episódio. Elas foram pensadas e inseridas posteriormente, pois percebemos a necessidade de criarmos atividades que simbolizassem o período de transição temporal do primeiro para o segundo episódio, que na ficção foi de um ano. Como o processo de "separação" das duplas foi intenso, no primeiro grupo que fizemos o processo, houve resistência da maioria dos participantes em assimilar a passagem de tempo, logo as atividades propostas demoraram mais para acontecer. Por isso inserimos este jogo para criarmos o distanciamento necessário para a passagem temporal.

\section{De volta ao muro:}

$\mathrm{Na}$ posição que estavam antes do intervalo. De olhos fechado, ao nosso sinal abriram os olhos. Essa ação simbolizou a volta aos papéis do primeiro episódio.

\section{Nossa comunidade:}

Cada um de nós, nos papéis de coordenadores dos "grupos de fronteiras", recepcionamos um dos grupos. Ambos com o intuito de formar equipes para proteger as fronteiras dos dois países. Nessa atividade, o objetivo do teacher in role era o de inserir elementos que pudessem fazer com que um lado desconfiasse do outro lado. Foram lançados os seguintes questionamentos aos participantes: qual o nome deles (no caso do papel criado), profissão e como pretendiam ajudar nessa missão? É importante ressaltar que foi dado aos participantes a instrução de que foi uma escolha deles estarem neste novo lugar, e que não se sabia ao certo porque seus "pares" não estavam ali.

\section{Nosso hino e bandeira:}

Inspirada no "Episódio 2. A chegada ao novo lugar: teremos que dividir a terra nova?" (VIDOR, 2010, p. 56-57). Cada grupo teve uma missão, confeccionar uma bandeira, criar um grito de guerra (ou hino) e o nome do seu "grupo de fronteira". 
Depois de executarem a tarefa foram para frente do muro e apresentaram seu grito e bandeira, o objetivo era que cada grupo ouvisse o outro. Depois de um tempo, cada representante do governo sai, e é dada aos participantes a instrução de que “independente do que possa acontecer, a comunicação entre os dois grupos é proibida". Essa instrução foi dada com o intuito de promover o contrário da mesma, ou seja, que os grupos começassem a estabelecer comunicação. Em cada lado do grupo havia uma caixa com papais, pinceis, canetas e lápis de cor, que foram usados tanto para confeccionar as bandeiras, quanto para instigar os participantes a criar meios de comunicar com o outro lado. O que aconteceu nos três processos, a confecção de bilhetinhos, cartas ou mensagens subliminares nas próprias bandeiras de cada grupo.

\section{Áudio sobre passagem de tempo:}

Depois de alguns minutos, inserirmos um áudio, e apagamos as luzes. O áudio demarcava o final do segundo episódio. Conteúdo do áudio:

\footnotetext{
"Acalmou a tormenta, pereceram os que a estes mares ontem se arriscaram e vivem os que por amor tremeram e dos céus os destinos esperaram" ". Passaram dois anos, vocês cumpriram sua missão. Foram bem-sucedidos nessas terras. Como vocês bem sabem o governo dos dois países mudou. O congresso de cada país, em comum acordo, decidiu que os grupos de fronteiras tenham autonomia para escolherem se querem continuar vivendo nesta comunidade e recebendo recursos para proteger o muro ou se querem derrubar o muro e ver se é possivel conviver com os outros, com aqueles que estão do outro lado. E então, a escolha é de vocês. O muro caíra ou o muro se manterá?
}

\section{Segundo encontro}

No processo realizado no Curso Partilhas Teatrais em Extensão, houve um intervalo de quatro dias entre o primeiro encontro (que ocorreu numa terça-feira) e o segundo (no sábado). Nesse intervalo nos reunimos (Flávia e Wellington) para elaborarmos as atividades do segundo encontro. Para isso, levamos em consideração as improvisações que surgiram e o retorno dos participantes, nos inspiramos em duas

\footnotetext{
${ }_{4}^{4}$ Trecho da letra da música Diáspora (TRIBALISTAS, 2017)
} 
atividades desenvolvidas no "Episódio 4. Derrubar ou preservar?" (VIDOR, 2010, p. 58-59), mais especificamente na tomada de decisão por manter ou não o muro, e na confecção do memorial, que no nosso caso foi um mural do processo.

\section{Terceiro episódio - dois anos depois}

\section{Conversa inicial, retomada do hino/bandeira:}

Relembramos sobre a passagem do tempo. Assumimos novos papeis: mediadores dos dois países. Foi dado um tempo para reestruturar a bandeira (caso essa tenha estragado). E relembrar o hino.

\section{O áudio:}

Colocamos novamente o áudio sobre a passagem de tempo. Nesse episódio os participantes retomaram os papéis criados no encontro passado, e nós, coordenadores, assumimos papeis de mediadores do governo de cada país. Tínhamos a missão de mediar a decisão dos moradores de cada lado da fronteira sobre manter ou derrubar o muro. Pedimos que fizessem uma lista com os motivos que os levariam a tomar tal decisão.

Tomada de decisão:

Os dois grupos comunicaram um ao outro sua decisão. Novamente os coordenadores, agora nos papéis de mediadores, tiveram que improvisar a partir dos argumentos expostos. Nas três vezes que fizemos o processo os grupos começaram com decisões diferentes. No módulo do Partilhas, o grupo que buscava a preservação da natureza estava dividido entre derrubar e manter o muro, enquanto o outro lado, o dos que defendiam a tecnologia, estavam certos em relação a derrubada do muro. Mas no final, após exporem vários argumentos, os grupos acabaram por derrubar o Muro.

Como se tratava criações baseadas em improvisações, apesar de termos alguns possíveis desfechos, não sabíamos o que poderia acontecer. Tínhamos apenas certo que se os grupos decidissem sobre a derrubada do muro, quando a mesma acontecesse, colocaríamos a música Um só dos Tribalistas, e ao término da mesma o jogo dos papeis 
se findaria. E assim, aconteceu nos três processos da Diáspora. E caso a decisão fosse contrária, encerraríamos o processo dizendo que iríamos comunicar aos governantes dos dois países sobre a decisão dos grupos em relação à manutenção do muro e os participantes escreveriam no muro as razões para que ele fosse sempre mantido.

No caso do processo realizado dentro do Partilhas o grupo decidiu abrir uma passagem no muro, ele não foi destruído por completo, foi feita uma abertura para que se pudesse transitar entre os dois locais, no entanto, o lado da "natureza" foi trazendo um a um do lado "tecnológico", até que todos estivessem juntos em um mesmo lado do muro. Já nos outros dois processos realizados foi optado pela destruição total do muro.

\section{Quarto episódio - mural coletivo}

Fora dos papéis. Pegamos pedaços do papel kraft que compunha o muro, colocamos no chão e fizemos uma roda ao seu redor. Em volta pinceis atômicos. Esse momento foi dedicado à criação de um mural coletivo. A instrução dada foi: "como vocês acham que seria daqui para frente? O que aconteceria com essa sociedade?". Cada um escreveu ou desenhou como pensava ser essa sociedade após a derrubada do muro. Ao final abrimos para um debate com o intuito de avaliarmos o processo.

\section{Considerações sobre o processo}

Como mencionado acima, fizemos o processo de Drama Diáspora em três momentos distintos de trocas entre os autores, ambos no ano de 2017. O primeiro no Curso Partilhas Teatrais em Extensão, o segundo no componente curricular Pedagogia do Teatro II do Curso de Teatro UFU e o terceiro no subprojeto Teatro PIBID do curso de Artes Cênicas UFGD. A estrutura dos três processos contou com pequenas adaptações de um local para outro, para melhor fluir do processo. Os resultados em cada uma das práticas tiveram várias semelhanças e algumas diferenças. Nessas considerações, focaremos na análise do processo que fizemos no Curso Partilhas Teatrais em Extensão (IMAGENS 1 e 2), ou seja, a primeira experiência do Drama 
Diáspora, desenvolvido com professores da rede de educação básica da cidade de Uberlândia.

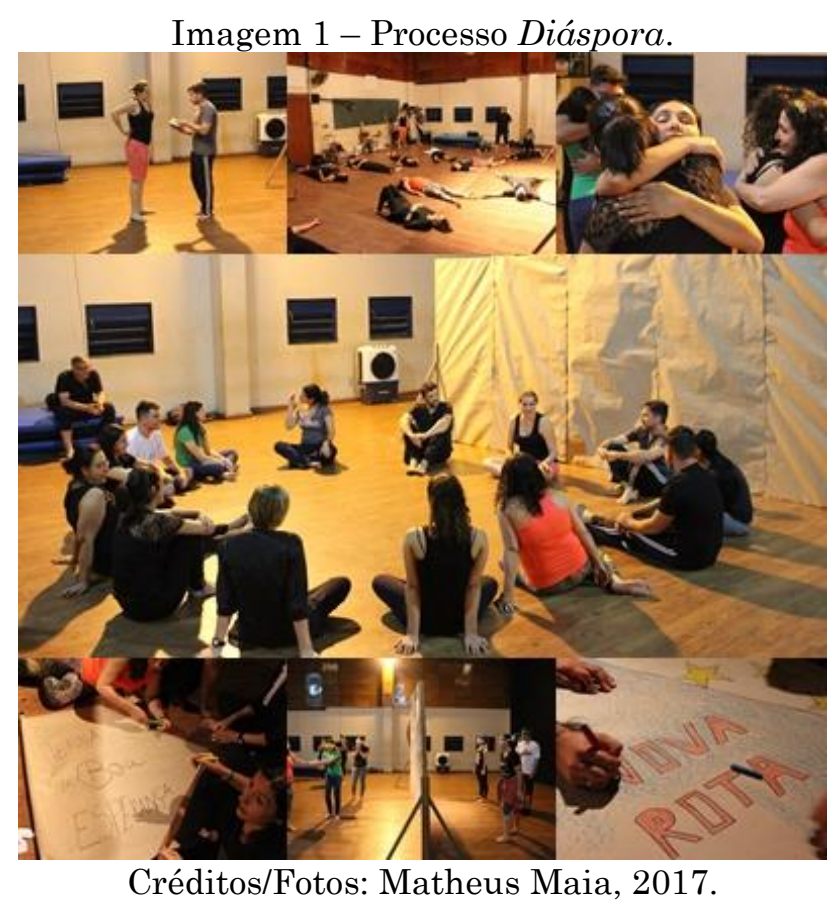

Essa nossa primeira partilha foi uma experiência potente, a partir da temática proposta os participantes trouxeram à tona inúmeras questões pessoais, sociais e políticas. "Embarcaram" na proposta do Drama e permitiram deixar-se tocar e se envolver com o processo. Foram receptivos com as propostas, em parte porque já conheciam o Curso Partilhas Teatrais em Extensão e estavam fazendo os módulos há alguns meses. Outro fator que talvez possa ter despertado o interesse nesse módulo, foi o fato de que o Drama ainda é pouco conhecido no Brasil, e apesar de atualmente existir certa diversidade de material bibliográfico sobre o assunto, vivenciar uma prática pode trazer estímulos para a realização de uma estrutura na instituição de ensino que o (a) professor (a) trabalha. Neste sentido foi interessante o relato dos (as) professores (as), alguns disseram que participar do Drama Diáspora abriu possibilidades de futuramente desenvolverem um processo nas escolas que atuam, uma vez que vivenciaram na prática um pouco da teoria lida em outros momentos de suas trajetórias. 


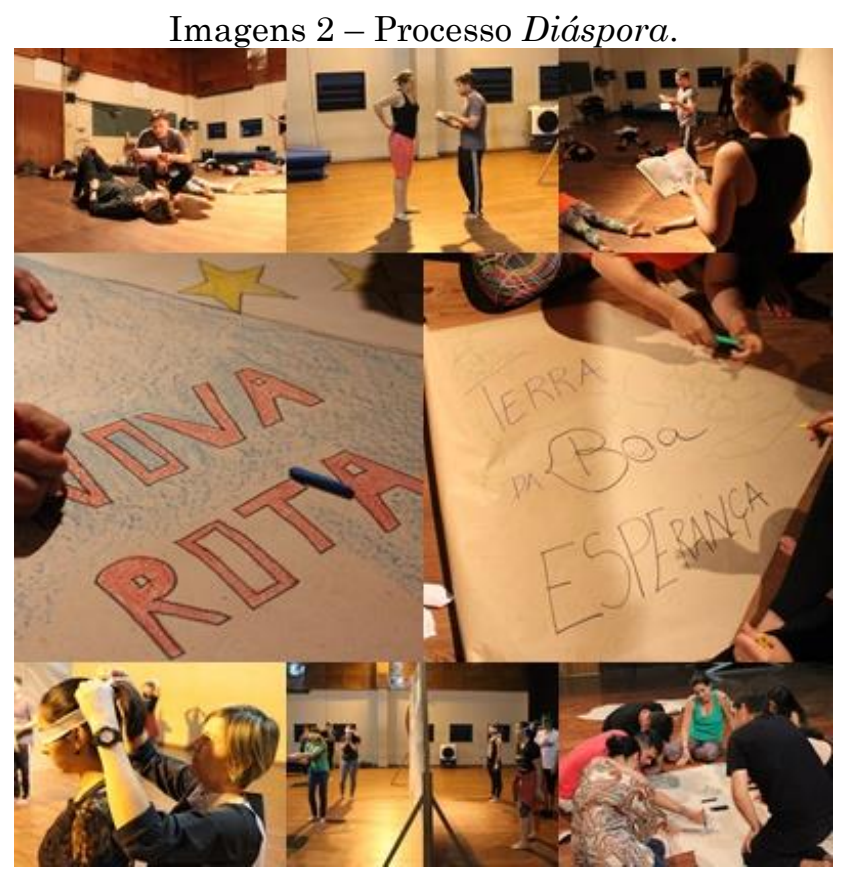

Crédito/Fotos: Matheus Maia, 2017.

O processo aliado à temática escolhida abriu um leque de discussões. Talvez o fato de se trabalhar em episódios com uma narrativa aberta e fragmentada, possibilitou aos participantes trazerem questões pessoais que reverberaram e foram acolhidas pelo grupo. No caso do Partilhas o foco se encaminhou para questões políticas, em especial de como construímos muros diariamente para isolar o outro que não tem a mesma visão política que a minha. Ao mesmo tempo em que nossos governantes e representantes políticos constroem outros muros que nos separam e por vezes nos instigam à paranoia nas redes sociais e relações interpessoais.

Mesmo com a imersão do grupo no processo, havia o distanciamento e a noção de que estavam participando de uma narrativa cênica alimentada por jogos e improvisações, isso possibilitou que através das atividades propostas os participantes refletissem sobre suas próprias realidades, e projetassem no contexto de ficção suas ideais, medos, opiniões etc. $\mathrm{O}$ contexto de jogo serviu como metáfora para trazer à tona questões relevantes aos participantes. Ao transitarem entre realidade e ficção, cada integrante traçou um percurso próprio enquanto seguia o trajeto da narrativa proposta, o que gerou um diálogo com a temática e um passeio por suas diversas significações. Foram convidados a compor coletivamente e em processo uma narrativa 
teatral, que misturava recortes do contexto de ficção elaborado previamente por nós, e as criações tecidas por todos durante as improvisações e os momentos de tomada de decisão.

Para nós, partilhar esse processo foi um momento de aprendizado e crescimento profissional em nossas trajetórias. O Curso Partilhas Teatrais em Extensão possibilitou que mesmo separados por uma distância geográfica de mais de mil quilômetros, conseguimos realizar um desejo antigo, o de estruturar e partilhar uma prática pedagógica. Entender e participar do trabalho um do outro foi uma maneira de reciclar e abrir horizontes de pesquisa e perspectivas artísticas e pedagógicas. As partilhas com professores da educação básica e estudantes nos possibilitaram conhecer pessoas vindas de vários lugares e juntos partilhamos o desejo de fazer teatro.

\section{$* * *$}

\section{REFERÊNCIAS}

ANTUNES, Arnaldo; BROWN, Carlinhos; MONTE, Marisa. Diáspora. Álbum Tribalistas. 2017

ANTUNES, Arnaldo; BRÁS, Antunes; BROWN, Carlinhos; MONTE, Marisa. Um só. Álbum Tribalistas. 2017

CABRAL, Beatriz. Drama como método de ensino. São Paulo: Hucitec: Edições Madacaru, 2006. (Pedagogia do Teatro)

CAMPTON, David. Nós e Eles. Leicester/U, 1977.

DESGRANGES, Flávio. O drama: construção coletiva de uma narrativa teatral. In:___ Pedagogia do Teatro: provocações e dialogismo. 2. ed. São Paulo: Hucitec: Edições Mandacaru, 2010. (Pedagogia do Teatro)

PAULA, Wellington Menegaz de. Drama-processo e ciberespaço: o ensino do teatro em campo expandido. Doutorado em Teatro - Centro de Artes, Programa de 
Pós-graduação em Teatro, Universidade do Estado de Santa Catarina, Florianópolis, 2016.

RODRIGUES, Nelson. Boca de Ouro. In: MAGALDI, Sábado (Org.). Teatro completo de Nelson Rodrigues: tragédias cariocas. Introdução Sábado Magaldi. Rio de Janeiro: Nova Fronteira, 1985.

. Vestido de Noiva. In: MAGALDI, Sábado (Org.). Teatro completo de Nelson Rodrigues: peças psicológicas. Introdução Sábado Magaldi. Rio de Janeiro: Nova Fronteira, 1981.

VIDOR, Heloise Baurich. Drama e teatralidade: o ensino do teatro na escola. Porto Alegre: Mediação, 2010.

Recebido em outubro de 2018. Aprovado em dezembro de 2018. Publicado em dezembro de 2018. 